\title{
Identifying adequate models in physico-mathematics: Descartes analysis of the rainbow
}

\author{
Albrecht Heeffer \\ Post-doctoral fellow of the Research Foundation Flanders (FWO Vlaanderen). \\ Ghent University, Belgium \\ albrecht.heeffer@ugent.be
}

Summary. The physico-mathematics that emerged at the beginning of the seventeenth century entailed the quantitative analysis of the physical nature with optics, meteorology and hydrostatics as its main subjects. Rather than considering physicomathematics as the mathematization of natural philosophy, it can be characterized it as the physicalization of mathematics, in particular the subordinate mixed mathematics. Such transformation of mixed mathematics was a process in which physicomathematics became liberated from Aristotelian constraints. This new approach to natural philosophy was strongly influenced by Jesuit writings and experimental practices. In this paper we will look at the strategies in which models were selected from the mixed sciences, engineering and technology adequate for an analysis of the specific phenomena under investigation. We will discuss Descartes analysis of the rainbow in the eight discourse of his Meteorology as an example of carefully selected models for physico-mathematical reasoning. We will further demonstrate that these models were readily available from Jesuit education and literature.

Key words: Model-based reasoning, material models, rainbow, optics

\subsection{The new physico-mathematics}

The physico-mathematics that emerged at the beginning of the seventeenth century entailed the quantitative analysis of the physical nature with optics, meteorology and hydrostatics as its main subjects. Isaac Beeckman after his encounter with Descartes in 1618, wrote in his Journal that there are not many students of physico-mathematics. ${ }^{1}$ While they understood physicomathematics as a new discipline, the term was previously used within the

\footnotetext{
1 [7], I, 244: "Dicit tamen se nunquam neminem reperisse, praeter me, qui hoc modo, quo ego gaudeo, studendi utatur accuratèque cum Mathematicâ, Physicam jungat. Neque etiam ego, praeter illum, nemini locutus sum hujusmodi studij”.
} 
Aristotelian tradition, denoting related disciplines known as mixed mathematics [22]. Although care should be taken with the use of the term (as argued by Maarten Van Dyck [25]), as it seems that its use in the early seventeenth century already reflects an important semantic shift and change in practices. Mixed mathematics functioned as an intermediate between natural philosophy and pure mathematics, but were considered subordinate to them. Rather than considering physico-mathematics as the mathematization of natural philosophy, John Schuster [22] has characterized it as the physicalization of the subordinate mixed mathematics. Such transformation of mixed mathematics was a process in which physico-mathematics became liberated from Aristotelian constraints.

Peter Dear [6] has shown how this new approach to natural philosophy was strongly influenced by Jesuit writings and experimental practices. Representatives of the tradition, such as Mydorge, Descartes, Mersenne and Cassini were educated at Jesuit colleges while others, such as Fabri, Grimaldi and Scheiner were Jesuits themselves. In this paper we will look at the strategies in which models were selected from the mixed sciences, engineering and technology adequate for an analysis of the specific phenomena under investigation. We will discuss Descartes analysis of the rainbow in the eight discourse of his Meteorology as an example of carefully selected models for physico-mathematical reasoning. We will further demonstrate that these models were readily available from Jesuit education and literature.

\subsection{Material models for discovery in natural philosophy}

Many studies since the late 1990s have demonstrated the importance of models in different aspects of scientific practice. Basic scientific processes such as discovery, explanation, simulation, representation, and experimental design have all been approached as forms of model-based reasoning. These models have been studied from philosophy of science [11], [18] as well as from cognitive science [16], [17]. The models we are interested in are representational models for physical phenomena. Such models typically bear an isomorphic relation to the phenomena observed. However, it is usually through abstraction and idealization that models reveal their heuristic function for the study of natural phenomena. Natural philosophers or scientists arrive at new laws and theories by isolating the relevant features of phenomena in an experimental configuration and excluding the unnecessary and contingent aspects. They do so by carefully selecting those models that facilitate the process of exclusion and isolation. Often a single model will not suffice and the discovery process may therefore involve several related models that allow focusing on one specific aspect more precisely.

As a prime historical example for the use of models in scientific discovery we may refer to Descartes analysis of the optical principles behind the rainbow. While several accounts on the rainbow were available by the 1620 s 
it was Descartes who first succeeded in publishing a satisfactory explanation why the primary and secondary rainbow are always seen under a given angle, why the colors always appear in the same order and why this order is inverted in the second rainbow. He argued his findings by a geometrical analysis of the twofold refraction and single reflection in a raindrop; a corpuscular explanation of light and carefully supported his results by precise quantitative observations. This analysis is presented as the eight discourse of the Meteorology, as part of Descartes ground breaking publication Discours de la méthode from 1637. Descartes included the discourses on Meteorology and Dioptrics as an illustration of his general method to arrive at certain and undoubtable knowledge in natural philosophy. As is well established, Descartes line of explanation in many of these discourses does not faithfully follow his method or his actual path to discovery. (e.g. for the sine law of refraction [12]). Though, for his analysis of the rainbow he explicitly stated that he does. This is one of the reasons for us to take up this example as a case study. Descartes analysis of the rainbow, conceived as an illustration of his general method, has been the subject of several historical and philosophical studies, notably by Carl Boyer [4], Richard Westfall [24], A.I. Sabra [19], William Shea [21], and what must be the definite account by Jed Buchwald [4]. We will therefore limit this contribution to the specific use of models and the context in which these models became available at the beginning of the seventeenth century. We will argue that Descartes could draw his models from Jesuit writings on physico-mathematics as well as popular accounts of disputations organized on these subjects.

\subsection{The models}

Descartes' analysis of the rainbow, which according to his own account follows his path of discovery, ${ }^{2}$ is based on a succession of different models to isolate the relevant features of a configuration and exclude the unnecessary and contingent aspects. As the rainbow is a natural phenomenon which can only be observed occasionally, the models facilitate experimental procedures to test and measure a given configuration. We can distinguish the use of five models in the eighth discourse:

\footnotetext{
${ }^{2}$ From a letter from Descartes to Vatier, February 1638, [9], I, 559-660: "Nor could I show the use of that method in the three treatises that I included, since it prescribes an order of investigation which is different enough from the order I believed I must use in order to explain them. However, I have given a sample of it in describing the rainbow, and if you take the trouble to reread it, I hope it will satisfy you better that it did the first time". Translation from [1], 86.
} 


\subsubsection{Artificial rainbows in fountains}

As a natural phenomenon, rainbows can only be observed in specific meteorological circumstances. There has to be a specific combination of rain and sun and the position of the sun should not be higher than 42 degrees. However, the appearance of rainbows can be modeled by artificial rainbows in fountains where they can be observed during a longer period. In the introduction of his treatise, Descartes uses the occurrence of rainbows in fountains as an argument for the reproducibility of this natural phenomenon ([9], VI, 325; [10], 332 ).

First, taking into consideration that this arc can appear not only in the sky but also in the air near us whenever there are drops of water in it that are illuminated by the sun, as experience shows us in certain fountains.

In the last part of the discourse he comes back to fountains and suggests the use of liquids with a higher refractive index for theatrical purposes ([9], VI, 343; Olscamp 344-5).

And this makes me remember an invention for making signs appear in the sky, which would cause great wonder in those who were ignorant of the causes. I suppose that you already know the method of making a rainbow visible by the use of a fountain. (..) To this it is now necessary to add that there are oils, spirits and other liquids, in which refraction is notably greater or lesser than in common water, and which are no less clear and transparent because of that.

\subsubsection{The spherical glass modelling a raindrop}

Descartes remarks that a raindrop can be modeled by a spherical flask filled with water (citeAT, VI, 325; [10], 332):

Then, knowing that these drops are round, as has been proven above, and seeing that their being larger or smaller does not change the appearance of the arc, I then took it into my head to make a very large one, the better to examine it. And for this purpose I filled a perfectly round and transparent large flask with water.

Descartes exploits the analogue of a flask with a very large raindrop to empirically come to an estimate on the angle under which the colors appear. He observes that for the color red the angle from the sun to the flask and back to the eye is approximately $42^{\circ}$. Moving the flask upwards makes the color change from red to yellow and then to the other colors of the rainbow. Descartes further determines experimentally that red reappears under an angle of around $52^{\circ}$ "but not as brilliant". 


\subsubsection{The prism}

In order to achieve a more accurate observation and to eliminate the double appearance of colors (caused by a second internal reflection in the raindrop), Descartes moves to a prism. The prism thus acts as a model in the same way as a spherical flask but allows him to isolate the color separation to a single refraction without reflections. Such a controlled experimental setup allows a more precise observation of the color separation. Descartes wants to know the precise order of colors and to determine what causes the separation of white light into colors. He used what was then known as a triangular glass (crystallo trigonam) (MNP in Figure 1.1).

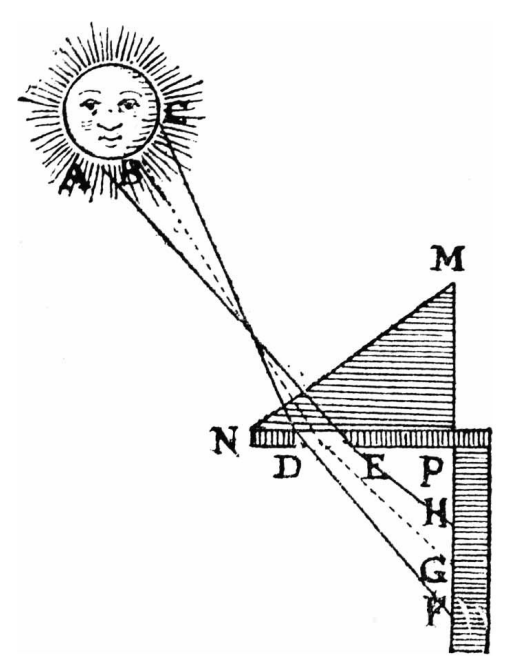

Fig. 1.1. The prism and aperture from the Meteorology by Descartes

\subsubsection{Wooden bowls}

In his corpuscular theory of nature, Descartes conceives of light as the result from movement of small spherical balls (Figure 1.2). These corpuscles can be modeled by wooden bowls as known from the game of Kayles (in French: quills) or billiard, or tennis balls as in his first and second discourse on Dioptrics, or even grapes as in the first discourse on Dioptrics. He uses balls as a model to explain that colors occur by differences in rotational speed of spherical particles. He further exploits tangible experience with these games for hypotheses on the kinetic behavior of corpuscules. A 'top spin' of a wooden ball (as used in billiard or tennis) causes the ball to rotate more than what is needed for a rotational movement on a surface. According to Descartes this corresponds 
with the color red. A 'slide' or middle hit causes the ball to slide and thus rotate less than needed for a rotational movement. This corresponds with blue light. Balls that follow the normal rotational movement on a surface will cause white light. The spin and slide effects on rotating balls are caused by a change of density in optical media and thus occur together with refraction.

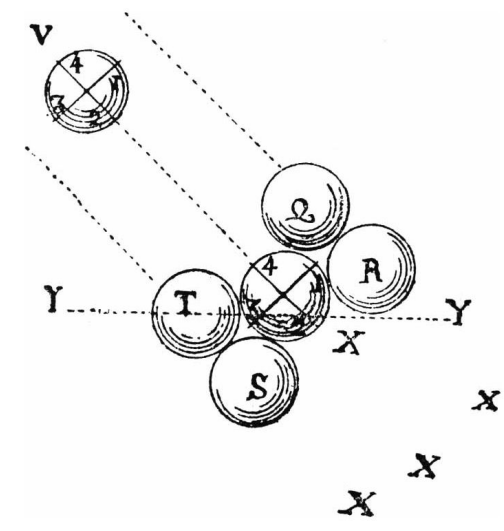

Fig. 1.2. The corpuscular explanation of color by Descartes

\subsubsection{The aperture}

In order to control the spread of colors by the prism, Descartes covers most of the refracting surface of the prism ( $D E$ in Figure 1.1). In doing so he adopts the model of an aperture controlling interactions between neighboring spheres. According to Buchwald [4] who reenacted the historical experiment, Descartes insisted on an aperture to create shade boundaries as he believed that light must interact with dark to generate color. Doing so, Descartes would adopt a transformed version of the Aristotelian theory of color as consisting of a mixture of black and white light. An alternative explanation which we favor is that Descartes was familiar with the camera obscura where the size of the aperture influences the quality of the image. It can be empirically established that the ideal width of the aperture is about one hundredth the distance between the aperture and the projected image. It was established only much later, by Lord Rayleigh that the optimal size of the aperture (d) is given by the formula $d=1.9 \sqrt{f \lambda}$, with $f$ as focal distance and $\lambda$ as the wavelength of light. For a focal distance of $50 \mathrm{~mm}$ this would amount to a very small aperture of $0.32 \mathrm{~mm}$. 


\subsection{Available models from Jesuit physico-mathematics}

For each of the models employed, we can identify specific sources that may have been a source of inspiration for Descartes. Jean-Robert Armogathe [2] argued that several of the "observations" by Descartes in the introduction of his eighth discourse on the rainbow stem from the Meteorologica published by Froidmont in 1627. While it may be the case that Descartes had read Froidmont's work by 1629, we instead will pursue the remark by Boyer that Descartes was inspired by the anonymous work Recreation mathematique [henceforth $R M$ ], first published at Pont-à-Mousson in $1624 .{ }^{3}$ According to Boyer ([3], 208) the treatment of rainbows in this book as something which eluded philosophers for a long time posed "a challenge which Descartes could not resist". The book has been wrongly attributed to the Jesuit Jean Leurechon. Elsewhere we have argued that the book was compiled from notes used for the public disputationes at the Jesuit college of Pont-à-Mousson, following closely a compendium of propositions on physico-mathematics authored by Jean Leurechon in 1622, bearing the title Selectae Propositiones [henceforth $S P$ ] [13]. The $R M$ and to a lesser extent, the $S P$, were well read, known and discussed by natural philosophers. The $R M$ is cited frequently in the correspondence of Beeckman, Descartes, Mydorge and Mersenne. Mydorge's compilation of notes and critical comments was added to the Moreau, 1626 edition and further expanded in the Mydorge edition of 1630. Mersenne, in his La verite des sciences of 1625 , freely took tens of pages of material from Leurechon's propositions on arithmetic, geometry and music (e.g. pp. 803812). His only acknowledgement is "comme ont remarqué les mathematiciens du Pont dans leur these de l'an 1622" (p. 803). Mersenne became aware of the $R M$ only later. The first reference to the book in his Correspondence dates from 27 April 1628. Robert Cornier wrote Mersenne about the volume and that it was expanded with a new third book (De Waard, Correspondance du P. Marin Mersenne, II, pp. 83-4). Another early work by Mersenne, Quaestiones celeberrime in genesis from 1623 also borrows from the Selectae propositiones. The figure on col. 95, is a description of a proposition taken from SP, Geometry, prop. X, p. 8.

The SP follows the Aristotelian view on the mixed sciences. Leurechon describes mechanics as subordinate to geometry and physics, while optics is subordinate to geometry (cited by Dear [6], 169. On the other hand, many of the propositions of the book deal with material models, machines, contrivances, mostly borrowed from Cardano's De subtilitate, and show a familiarity of engineering treatises from the early seventeenth century. Even subjects in pure mathematics, such as conic sections, are made tangible by two propositions in which inflexible bodies, like pyramids and cones, have to be passed through

\footnotetext{
${ }^{3}$ For a forthcoming critical edition of the English translation of this book see [13]
} 
geometrical figures cut in cardboard. ${ }^{4}$ These are two of the many propositions reproduced in the $R M$ (see Figure 1.3).

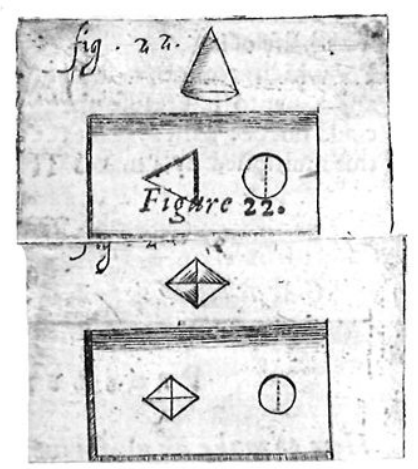

Fig. 1.3. Conic sections made tangible, from $R M$, problems 22-3.

In Descartes account on the rainbow we find that all of the five models he uses also appear in both the $S P$ and the $R M$. We list them in the same order:

\subsubsection{Artificial rainbows in fountains}

The description of the rainbow by Leurechon, appears in the $S P$, under Optics, prop. XX, p. $35 .{ }^{5}$ We here reproduce the full proposition:

Refraction and reflection depict various celestial and sublunary appearances, halos, parhelia, paraselenae, rainbows in clouds, in the prism, in glass jars, in multi-faceted crystals, in the arched water of splash fountains, in burning light of a candle. Here one sees with certainty that the colors that appear in these circumstances have a

\footnotetext{
${ }^{4} S P$, Geometry, prop. XII, p. 8: "Potest unum \& idem corpus solidum ac durum, per tria foramina transmitti, quorum unum sit rotundum, secundum quadratum, tertium ovale, ita ut singula in transitu compleat; potest aliud eandem conditione transmitti per rotundum, ovale \& quadrangulare quantaelibet longitudinis: aliud, per rotundum \& quandrangulare; alius per rotundum \& triangulare duntaxat".

${ }^{5}$ Refractio et reflexio, varia coelestibus ac sublunaribus pingit phasmata, halones, parelia, paraselenias, irides in nubibus, in crystallo trigonam, in ampulis vitreus, in polyoptris, in aquam fontium arcuaram et irroratam, in lucernic ardentibus. Ubi certum videtur, colores hic apparentes, causam habere congenerem, puta per mixtionem refractae lucis cum refrigente subiecto; figures autem diversas, incidentium, refractorum simul et reflexorum radiorum legibus gubernari. Probabile est, geminari posse lunarem iridem, sicut et solarem, sic tamen, ut secundaria iris non sit imago alterius ex reflexione producta.
} 
common cause, namely the mixture of the refracted light with the refractive subject; while the different figures that appear are governed simultaneously by the laws of refraction and reflection of the rays of light. It is probable that the moon rainbow can be doubled in the same way as the solar rainbow, yet in such a way that the second bow is not an image produced by a reflection of the first bow.

Problem 46 of the $R M$ (44 in the English editions) is an elaboration of this proposition. It includes the "experiment" to fill ones mouth with water and to blow it out through the lips, standing with the back to the sun. The author, in a remark omitted by the English translator, complains about the lack of an explanation on the rainbow:

I am afraid that you will ask me more; about the production, disposition and figure of these colours. I shall reply that they come by reflection and refraction of light, and that is all. (..) And he who said that it is the mirror in which human nature has had a full view of its ignorance has well understood; for all the philosophers and mathematicians who for so many years have been engaged in discovering and explaining its causes, have learned nothing except they know nothing but a appearance of truth

This was the challenge which, according to Boyer [3], Descartes could not let pass. Descartes also commences his eight discourse with the observation that several phenomena share a common cause. His references to the rainbow in fountains is indeed most likely to be inspired by $R M$. His remark "this makes me remember an invention for making signs appear in the sky, which would cause great wonder in those who were ignorant of the causes", cited above, is almost a literal quote from the book. ${ }^{6}$

\subsubsection{The spherical glass modelling a raindrop}

The spherical glass is already mentioned by Leurechon (ampulis vitreus), as quoted above. In $R M$ the glass is described as "a stable and permanent" configuration to observe the colors of the rainbow. ${ }^{7}$

\footnotetext{
${ }^{6}$ Compare Descartes, [9], VI, 343: "qui pourroient causer grande admiration a ceux qui en ignoreroient les raisons", with one of several similar formulations in $R M$ : "avec grand estonnement des assistans particulierement s'ils en ignorent la cause" (1630, p. 73).

7 From the English edition: 1633, 68: "But to have one more stable and permanent in his colours. Take a glass full of water, and expose it to the sun, so that the rays that pass through strike upon a shadowed place, you will have pleasure to see the fine form of a rainbow by this reflection".
} 


\subsubsection{The prism}

The use of a prism for color separation is described both in SP (crystallo trigonam) as in $R M(1633,68)$ :

Or take a triagonal glass, or crystal glass of divers angles; and look through it, or let the beams of the sun pass through it; or with a candle let the appearances be received upon a shadowed place: you will have the same contentment.

\subsubsection{Colliding bowls}

That mathematical principles govern the behavior of wooden of ivory balls on impact is discussed in SP, Geometry, $\mathrm{XV}:^{8}$

It is a pleasing quality of mathematics, so to play with ivory balls, or ebony and the like, according the laws of reflection, 1) on one plane, or else 2) impacting on more planes, to be shot at a specific location; or else 3) one ball pushed by the other, at whatever direction rolled forward, also attributed to, if you please, the various linear motions, and the collision at the various points of contact, whether in the plane, or within the perimeter of the circle.

The planes to which is referred to are the vertical rails, in later versions of the game table replaced by cushions. Leurechon describes three principles which apply to the balls movement without any spin: 1) the law of reflection describing the path when hitting the rail under a given angle, 2) directing the ball to a specific location by hitting the rail more than one time and 3) the effects of colliding balls.

This early reference to ball games should not surprise us. Mac Lean, in a $\mathrm{PhD}$ dissertation on the history of the laws of collision [15], describes the popularity of these games in France at the beginning of the seventeenth century. He points at the $R M$ as the first work in which ball games are analyzed by the laws of geometry. However, Cusanus used the game of bowling already in his De ludo globi of 1463, as a metaphorical tool for expounding his view on the cosmos. Although in this dialogue the bowling ball is most often used as a metaphor, in his argumentation Cusanus explains the laws governing the impetus and movement of the ball. As an example [5], I, 23:

\footnotetext{
${ }^{8}$ Mathematicae iucunditatis est, in sphaerulis eburneis, aut buxeis, et similibus, ita ludere, ut reflecionem legibis, una in planum, aut duo vel plura plana impingens, ad destinatum locum emittatur: vel ita una sphaerula, caeteras impellens, ad quamcunque volveris partem dirigat, assignatis etiam, si lubet, variorum motuum lineis, variorum contactuum et allisionum punctis, sive in plano, sive per ambitum circuli.
} 
PROBLEME 78 .

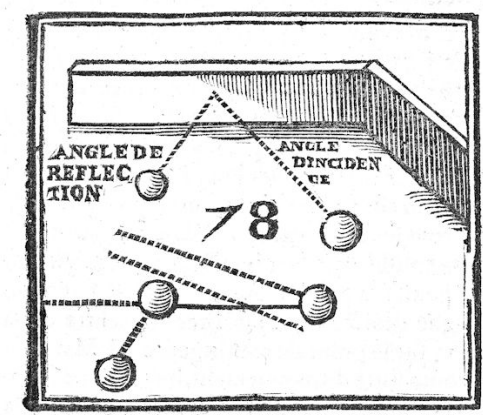

Du ieu de paurse, de Truc on de billart, $0^{\circ}$ paille-maille, or autres femblables.

Fig. 1.4. Geometrical analysis of billiard from Récréations Mathématiques, problem 78

Keep in mind that the motion of the bowling-ball ceases but that the ball remains intact; for the ball has no natural motion but has [only] an accidental and forced motion. Therefore, the ball stops moving when the impetus that was impressed upon it ceases. But if the bowling-ball were perfectly round, then (as was said earlier) its motion would never cease, because a circular movement would be natural to that ball and not at all forced upon it.

The Italian priest and Aristotelian philosopher Antonio Scaino da Salò (1524-1612), published in 1555 a treatise on giuoco della palla (jeu de paume or tennis), describing the rules of the game and the courts where it is played. He briefly touches upon the relation of the balls movement with the laws of natural philosophy, mainly concerning the principles of ballistics.

Problem 78 of RM, probably contains the first diagram used for a geometrical analysis of a ball game (see Figure 1.4. Here we find the three rules described by Leurechon applied to the game of billiard. ${ }^{9}$

And the first maxim is thus. When a bowl toucheth another bowl or when a trap stick striketh the ball, the moving of the ball is made in a right line, which is drawn from the centre of the bowl by the point of contingency. Secondly, in all kind of such motion, when a ball or bowl rebounds, be it either against wood, a wall, upon a drum, a pavement, or upon a racket, the incident angle is always equal to the angle of reflection.

${ }^{9}$ From the English edition which does not mention billiard but tennis and trapball. This reference to the game of trap-ball predates the earliest entry in the Oxford English Dictionary (1658). The figure is taken from the author's copy of the 1672 Lyon edition. 


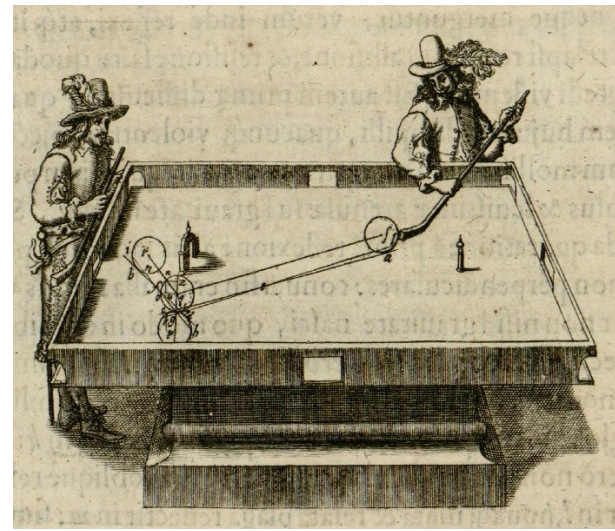

Fig. 1.5. A geometrical analysis of billard from Johannes Marcus's De Proportione Motus, 1636, p. 105

Now following these maxims, it is easy to conclude:

First, in what part of the wood or wall one may make the bowl or ball go to reflect or rebound, to such a place as one would.

Secondly, how one may call a bowl upon another, in such sort that the first or the second shall go and meet with the third, keeping the reflection or angle of incidence equal.

Thirdly, how one may touch a bowl to send it to what part one pleaseth, such and many other practices maybe done. At the exercises at kayles there must be taken heed that the motion slack or diminish by little and little, and may be noted that the maxim of reflections cannot be exactly observed by local motion, as in the beams of light, and of other qualities, whereof it is necessary to supply it by industry or by strength otherwise one may be frustrated in that respect.

Descartes explains in his discourse on refraction of the Dioptrique the causes of refraction by means of an idealized tennis ball (jeu de paume) hitting a piece of loosely woven cloth. The second discourse on refraction does not mention a tennis ball explicitly but Descartes refers to the game in the first discourse in describing the effect on the motion of the ball impacting on a surface. He further explains that the different effects the ball or corpuscule, correspond with the different colors of light (AT, VI, 90-91):

Those who play tennis can prove this sufficiently, when their ball encounters uneven ground, or else when they hit it obliquely with their racket, which they call, I believe, cutting or grazing (..) Some reflect these rays without causing any other change in their action, such as those which we call white, and the others carry with this reflection a change similar to that which the movement of a ball receives when we 
graze it, such as those which are red, or yellow, or blue, or any other such color.

In the fifth discourse of the Dioptrique on the anatomy of the eye and in the Meteores on the rainbow, the acceleration and slip of wooden balls further serves as a model for the behaviour of spherical corpuscules and the causes of color.

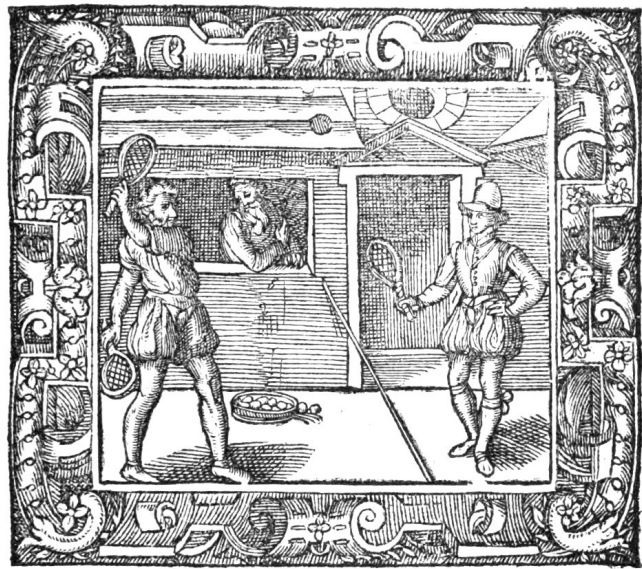

Fig. 1.6. The earliest depiction of tennis from Sambucus, Emblemata, 1564, p. 133

The model of the tennis ball further plays a role in the experimentum crucis of 1666 by Newton where he describes to the Royal Society his discovery of the cause for chromatics abberation in lenses: ${ }^{10}$

Then I began to suspect, whether the Rays, after their trajection through the Prisme, did not move in curve lines, and according to their more or less curvity tend to divers parts of the wall. And it increased my suspition, when I remembred that I had often seen a Tennis ball, struck with an oblique Racket, describe such a curve line.

\subsubsection{The aperture}

The the camera obscura is described as "that dioptrical instrument" in proposition XIX of the part on Optics. The aperture is called a (pupillae foramen). Leurechon further describes the use of a concave lens to reinvert the image and draws the parallel with the eye: "for philosophers, it is a fine secret to explaining the organ of the sight, for the hollow of the eye is taken as the

${ }_{10}$ Philosophical Transactions of the Royal Society, No. 80 (19 Feb. 1671/2), pp. 3075-3087. 
close chamber, the ball of the apple of the eye, for the hole of the chamber, the crystalline humour as the small of the glass and the bottom of the eye, for the wall or leaf of paper". The Jesuit must have been familiar with Kepler's Paralipomena in which the retinal image theory was first expounded. An elaborated version appears as problem 2 in $R M$ (see Figure 1.4.5. Both specifically mention to experiment with the aperture to achieve the best results. The translator of the English edition recommends an aperture of the size of a six pence coin.

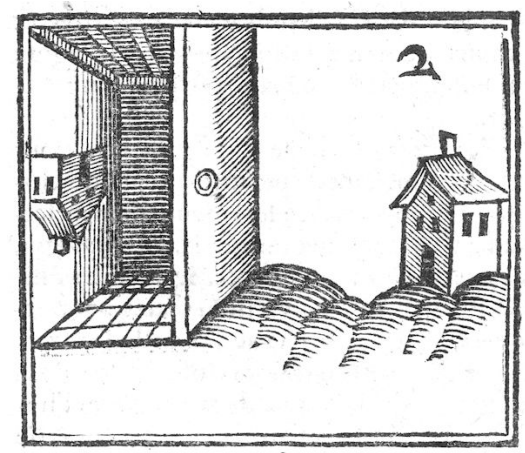

Fig. 1.7. The camera obscura from Récréations Mathématiques, problem 2

Descartes, in the fifth discourse on Dioptrics describes his experiences with the camera obscura in relation to the eye. Even without the use of a lens "certain images will certainly appear on the cloth, provided that the hole be quite small, but they will appear very confused and imperfect, so much more so as this hole is quite small" ([9], VI, 126; [10], 97). He further discusses the size of the image being proportional to the object as the focal distance is to the distance between the aperture and the object, and the quality of the image related to the distance to the aperture. His description reflects practical experience with the camera obscura. This supports our view that his use of the aperture on the prism was motivated by such experience.

The aperture was later also employed by Newton in the experiment cited above:

The gradual removal of these suspitions, at length led me to the Experimentum Crucis, which was this: I took two boards, and placed one of them close behind the Prisme at the window, so that the light might pass through a small hole, made in it for the purpose, and fall on the other board, which I placed at about 12 feet distance, having first made a small hole in it also, for some of that Incident light to pass through. 
Not only where these models for the analysis of the rainbow readily available in $R M$, Descartes also shares the admiration and the principle of wonder with the book. In the last paragraph he writes: this makes me remember an invention for making signs appear in the sky, which would cause great wonder in those who were ignorant in the cause. The invention he talks about is an optical experiment described in $R M$ and his definition of wonder as admirables pour ceux qui en ignorent la cause (repeated from discourse 7) echoes a frequent remark from $R M$. Wonder is an epistemological quality it depends on our knowledge of the hidden causes. Descartes raises it to a methodological principle.

That the models borrowed by Descartes from $R M$ already appear in the witness account of the disputationes held at Pont-à-Mousson should not surprise us. The physicalization of mixed mathematics, as Schusters calls it, was happening already at the Jesuit colleges. Making mathematics tangible was part of a deliberate pedagogical strategy of the Jesuits to allure the nobility to their colleges. Even pure mathematics as conic sections was made tangible by experiments in which solid bodies (conic, cylindrical, pyramidal) were passed through a hole in a flat surface (both in $S P$ and $R M$ ). The physicalization of mathematics provided new opportunities for the use of models in physico-mathematics in which Descartes excelled.

\subsection{Negotiating models}

Until now we have discussed the successful models as used in Descartes' discovery and explanation of the causes of the rainbow. Evidently, such a sequence of five models, each highlighting some aspect of the phenomenon under investigation, does not comes as a single insight. Each discovery is preceded by a process of trial, experimentation and consideration, to find out what the most adequate models may be. Typically for Descartes, we do not find anything of such considerations in his published work. However, the correspondence in the circle of Marin Mersenne provides a witness account of the negotiations on the choice of adequate models for the analysis of specific phenomena.

One interesting example related to color separation is the halo seen around a burning candle (Figure 1.8). Leurechon, (SP, Optics, prop. XX, p. 3) already

placed it on the same level as the rainbow. Also in RM, the appearance of colors around the flame is compared to the spherical glass filled with water: "or with a candle let the appearances be received upon a shadowed place: you will have the same contentment". Mersenne repeatedly observed a colored corona around the flame of a candle, and discusses the phenomenon in his treatise on the rainbow, written between 1625 and 1627 ([8], II, 649-). However, from his correspondence it appears that Descartes "is astonished to hear" that Mersenne observed the phenomenon while he himself "rubbed and rolled [his] eyes in all sorts of ways to try to see something similar, but with no success" (Descartes to Mersenne 18 Dec 1629, [9], I, 83). A little later Descartes writes 


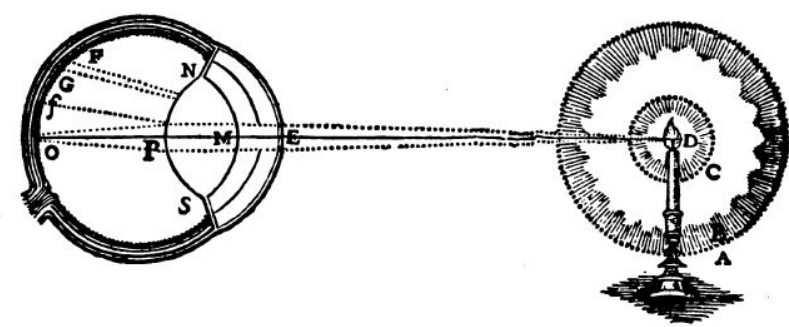

Fig. 1.8. Descartes' entopical explanation of a halo around a candle

Mersenne that this should not be confused with the corona seen around stars and is to be explained as secondary light coming from the rays which pass straight through the iris (Descartes to Mersenne, January 1630, [9], I, 106). Descartes' view is confirmed by an experience on a boat in Holland, which he reported to Golius on 19 May 1635 ([9], I, 318-9): "What this taught me was that the coronas were arranged in exactly the opposite way to those which appear around stars, i.e. red and the outside, and that they did not form in the air, but simply in the water of one of my eyes". Later again, in the ninth discourse of his Meteoroloy, he refers to this incident and proposes an explanation of the halos based on the particles on the cornea of the eye ([9] VI, 351-354; [10], 350-1): "their cause must be sought, not in the air, but only in the eye which looks at them". This explanation corresponds with an entry in Beeckman's Journal of 1632. ${ }^{11}$ Others like Pierre Gassendi and the Jesuit Claude Dechales instead believed that the phenomenon was caused by the same principles as the rainbow, by dispersion of light. Such differences in opinion cannot be settled in one way or the other. In fact, both explanations have their value. Ocular halos do exist as conjectured by Descartes while halos can also appear around light sources by dispersion of light through ice crystals. Interesting from a historical standpoint is that natural philosophers were involved in a process of negotiation on the adequate models for the study of specific phenomena. In Descartes' view, the halo around the flame of a candle is a better model for studying entopical diffraction phenomena than for the dispersion of light [23]]. Others believed that the flame of candle was a suitable model for studying the causes of color separation. These discussions show us how the selection of adequate models was a process of argumentation and negotiation.

$\overline{11}$ [7], III, 237: "Iris oculi est humor corneae concavo adhaerens a parte sui pupillae, limbum (ubi lux dissolvens humores, est debilior quam in medio) inficiens, id est tegens. Hinc sequitur iridem circa candelam, aut quodvis lumen pupilla majus, visam, eo videri majorem quo lumen id est ab oculo remotius". 


\subsection{Conclusion}

The five models that are used in Descartes analysis are no sophisticated or abstract mathematical models but are rather derived from artifacts or simple technological devices. We have pointed out that 1) the appearance of a rainbow in a fountain, 2) the analogy of a raindrop with a spherical flask filled with water, 3) the kinetic behavior of wooden or ivory balls, 4) the appearance of colors in a prism and 5) the aperture in a camera obscura all appeared as propositions that were the subject of discussion at Jesuit colleges during the disputationes amongst students. Descartes was educated at such a college and was strongly influenced by the Jesuit attempts to physicalize pure and mixed mathematics as part of a pedagogical strategy. He explicitly mentions in his Principles of Philosophy that he draws much inspiration from daily artifacts ([9], VIIIA, 236, tr. Cottingham):

In this matter I was greatly helped by considering artefacts. For I do not recognize any difference between artefacts and natural bodies except that the operations of artefacts are for the most part performed by mechanisms which are large enough to be easily perceivable by the sensesas indeed must be the case if they are capable of being manufactured by human beings.

Rather than setting up highly contrived experiments, Descartes believes that natural phenomena are better studied by common situations with which we are familiar in daily situations [9], VI, 63, tr. Cottingham): "rather than seeking those which are more unusual and highly contrived, it is better to resort only to those which, presenting themselves spontaneously to our senses". Descartes may have acquired his taste for experience with natural objects and simple artifacts from his days at the Jesuit college of La Flèche (1606 - 1616). He certainly believed that his approach to physico-mathematics is useful for Jesuit education, as he is recommending his analysis of the rainbow in a letter to Fournet, J.S. of October 1637 ([9], I, 455):

It seems to me that there is no-one who has a greater interest in examining this book than the members of your Society, for I can already see that what it contains (especially as far as meteorology is concerned) will be accepted by so many people that I just do not know how they will be able to teach these subjects without either refuting or accepting what I have written.

\section{References}

1. Ariew Roger (2000) (tr.) René Descartes. Philosophical essays and correspondence, Hacket Publishing, Indianapolis. 
2. Jean-Robert Armogathe, J-R., "The Rainbow: A Privileged Epistemological Model", in S. Gaukroger, J. Schuster and J. Sutton (eds.), Descartes' Natural Philosophy, (London, 2000), 249-57.

3. Boyer, C., The Rainbow. From Myth to Mathematics, (New York: Sagamore Press, 1959).

4. Buchwald, J., Descartes's Experimental Journey Past the Prism and Through the Invisible World to the Rainbow, Annals of Science, 65 (1), 146.

5. Nicholas of Cusa, De ludo globi, 1463, (English translation by Jasper Hopkins, Metaphysical Speculations, vol. 2, The Arthur J. Banning Press, Minneapolis, 2000).

6. Dear, P. Discipline and Experience: The Mathematical Way in the Scientific Revolution, Chicago: Chicago University Press, 1995.

7. de Waard C. (ed.) Journal tenu par Isaac Beeckman de 1604 à 1634. Tome 1: 1604-1619, Martinus Nijhoff, Den Haag, 1939.

8. Mersenne, M. Correspondance du P. Marin Mersenne, Religieux Minime, publiée et annotée par Cornelis de Waard ; avec la collaboration de Armand Beaulieu ; édition entreprise sur l'initiative de madame Paul Tannery et continuée par le C.N.R.S, Editions du Centre national de la recherche scientifique (1932-1988), 18 vols.

9. Descartes, R., Oeuvres de Descartes (11 vols). Charles Adam and Paul Tannery (eds.) Paris: Librairie Philosophique J. Vrin, 1983.

10. Descartes, R., Discourse on Method, Optics, Geometry and Meteorology, translated by P. Olscamp, Hackett, Indianapolis, IN, 2001.

11. Giere, R., Explaining Science: A Cognitive Approach. Chicago: University of Chicago Press, 1988.

12. Heeffer, A. "The Logic of Disguise: Descartes Discovery of the Sine Law", Historia Scientiarum. International Journal of the History of Science Society of Japan, 16 (2), November 2006, 144-165.

13. Heeffer A (2012) "Wonder to those that are ignorant in the cause", A critical English edition of Récréations Mathématiques (1624), with a glossary and commentaries, (Heidelberg: Springer, 2012) (forthcoming).

14. Leurechon, J., Selectae propositiones, Sébastien Carmoisy, Pont-à-Mousson, 1622 .

15. Mac Lean J., De historische ontwikkeling der stootwetten van Aristoteles tot Huyghens, PhD dissertation, Free University of Amsterdam, Van Sijn en zonen, Rotterdam, 1959.

16. Magnani, L; Nersessian, N.J.; Thagard P. (eds.) Model-based reasoning in scientific discovery, New York, Kluwer, 1999.

17. Lorenzo Magnani, L; Nancy J. Nersessian, (eds.) Model Based Reasoning, Science, Technology, Values, New York, Springer, 2002.

18. Meheus, J; Thomas Nickles (eds.) Models of Discovery and Creativity, New York, Springer, 2009.

19. Sabra, A.I., Theories of Light from Descartes to Newton, Cambridge, 1981.

20. Scaino, A., Trattato del giuoco della palla, Venice: Gabriele Giolito de'Ferrari and brothers, 1555, (Modern editions: a cura di Giorgio Nonni, Urbino Quattroventi 2000. Scaino on tennis, Translated into english by W.W. Kershaw at the instance of C.B. Gabriel, Honorary Secretary and Treasurer of the Royal Tennis Court 1932-1947; with acknowledgements, corrigenda and historical notes by P.A. Negretti. [London]: Strangeways Press, 1951). 
21. Shea, W.R., The Magic of Numbers and Motion. The Scientific Career of René Descartes, (Canton, MA, 1991).

22. John A. Schuster (2012) "Physico-Mathematics and the Search for Causes in Descartes' Optics - 1619 - 1637", Synthese, 185 (3):467-499.

23. Simpson, George C. Ocular haloes and coronas, British Journal of Ophtalmology, 37, 1953, $450-486$.

24. Westfall, R.S., "The Development of Newtons Theory of Color", Isis, 53 (1962) 339-580. Van

25. Van Dyck, M. “'Argumentandi modus huius scientiae maximè proprius ..' Guidobaldo's mechanics and the question of mathematical principles, in E. Gamba, A. Becchi, \& D. Bertoloni Meli (eds.) Mathematiche e tecnica da Urbino all'Europa. Berlin: Max Planck Research Library for the History and Development of Knowledge (forthcoming).

26. van Etten, H, Recreation Mathematique, Pont-à-Mousson: Jean Appier Hanzelet, 1624. 